\title{
Portraits of People Who Are Homeless in the Canadian Media: Investigating the Journalists behind the Stories
}

\author{
Katharina Kovacs Burns ${ }^{1}$, Solina Richter ${ }^{2} \&$ Jean Chaw Kant ${ }^{2}$ \\ ${ }^{1}$ Health Sciences Council, University of Alberta, Edmonton, Canada \\ ${ }^{2}$ Faculty of Nursing, University of Alberta, Edmonton, Canada \\ Correspondence: Katharina Kovacs Burns, Health Sciences Council 3-398 ECHA, University of Alberta, \\ Edmonton, Alberta, T6G 1C9, Canada. Tel: 1-780-920-8961. E-mail: kathy.kovacsburns@ ualberta.ca
}

Received: September 13, 2013 Accepted: September 27, 2013 Available online: October 22, 2013

doi:10.11114/smc.v1i2.219

URL: http://dx.doi.org/10.11114/smc.v1i2.219

\begin{abstract}
Homelessness is a complex social issue facing many communities in Canada, but most people, including policy makers have not talked or associated with someone who is homeless. Their experience is most often acquired through the skillfully framed stories of media journalists and reporters. How do journalists acquire their knowledge and frame the story in ways that impact and influence the public or policy makers in forming their perceptions? Why have they taken the position they have with the story? These and other questions about the journalists themselves, are rarely pursued, but are of value in revealing the motivation, objectivity and subjective biases in their story-telling. With social issues such as homelessness, this is of relevance as perspectives and decisions can be influenced which could have positive or negative consequences. Based on this premise, a mixed methods case study involving journalists' motivation for writing about homelessness and how they framed their stories was pursued. Our results reveal that journalists feel that social issues, such as homelessness, are more challenging to report about as they are personally affected with what they see and hear. Their personal experiences, as well as what they want others to feel, influence what and how they frame their reporting on this situation. They do want to impact the public and policy makers - increasing their awareness and advocating for changes. Their preferences for story topics, framing considerations and impact goals reveal who they are as the people behind the media stories.
\end{abstract}

Keywords: media, journalists, mass communication, framing, homeless, homelessness

\section{Introduction}

\subsection{Why Explore Media Journalists' Framing of People who are Homeless?}

Homelessness is a complex and challenging social issue for most of us to define, describe or understand (Gaetz, Donaldson, Richter \& Gulliver 2013; Hulchanski, Campsie, Chau, Hwang \& Paradis, 2009). The Canadian Homelessness Research Network (2012) describes, rather than defines homelessness as

the situation of an individual or household without stable, permanent, acceptable housing, or the immediate prospect of acquiring it. It is the result of systemic or societal barriers, a lack of affordable and appropriate housing, and/or the individual/household's financial, mental, cognitive, behavioural or physical challenges (p.1).

The majority of our perceptions of the people who are homeless or their circumstances are based on the stories we hear, or read about or see in the news media, rather than actual first-hand experiences. Journalists of news media frame their stories of people who are homeless and their situations through their words and pictures to elicit emotions, feelings, or reactions (Author, 2011; Cress \& Snow, 2000; Kendall, 2005). Through the journalists' skilled framing of the story, they can raise the public's and policy makers' awareness and influence their perceptions and possible actions (Iyengar \& Kinder, 2010).

Understanding how journalists frame their stories about people who are homeless or their situations, and why they write from the perspective they do, are important for several reasons: to understand the person writing the story and his/her context in relation to the subject matter; to appreciate the journalists' interpretations of homelessness and the people affected; and to weigh the objectivity along with the subjectivity in the framing of 
the story. Gaining this understanding of journalists and their views and framing of homelessness stories became the focus of a study we conducted with journalists in Alberta, Canada. In this paper, we summarize what we discovered from examining the literature and our findings.

\subsection{Alberta, Canada - Context in Relation to Homelessness, 2007-2013}

Over the past five years around the time of this study, Alberta experienced many changes with its population including those who were homeless, its cost of living and with its provincial policies regarding homelessness. The population increased from 3.4 million to nearly 3.8 million. The average cost of living increased substantially; housing prices increased as much as 65\% around 2008 (Faid, 2009). Vacancy rates were 0\% and inadequate housing became an issue. Alberta's Task Force on Affordable Housing, created in 2007, took action on homelessness, and A Plan for Alberta: Ending Homelessness in 10 Years, the first 'Housing First' plan in Canada was developed (Alberta Secretariat for Action on Homelessness, 2008). There were about 8,500 counted homeless in Calgary and Edmonton, with increases of $18 \%$ projected and a forecast of 21,222 by 2019, if no plan was instituted. The Housing First plan was estimated to save about $\$ 7.1$ billion. In 2009, the Alberta Government announced $\$ 3.2$ billion for the plan and by 2010, housing and support programs started in Calgary and Edmonton. A three-year progress report (Alberta Secretariat for Action on Homelessness, 2013) indicated a substantial reduction in homeless counts, some people successfully independent and housed, and other successes related to employment and a fresh start on life.

\subsection{Media Access by the Public}

The two major newspapers in Alberta, The Edmonton Journal and The Calgary Herald, have always had huge weekly readerships - averaging 516,000 in Edmonton between 2008 and 2012, and 552,100 in Calgary. At the same time $23 \%$ and $28 \%$ of adults, respectively, read online editions and HUB website newspapers, and social media users increased their access to Internet news but also watched more TV and listened to more radio than other adults (Newspaper Audience Databank Inc., 2007 - 2012).

\subsection{The Literature on Journalists - Their Framing of News and Influence on Public Opinion}

A paucity of literature exists on the framing of news topics in the media, the media's influence on public opinion and analysis of news content. We found very few studies focusing generally on the journalists' motivation for writing what they do, and fewer still on journalists' perceptions of homelessness. Our summary of the literature on the topic is not comprehensive and our analysis is focused on the content relevant to this study.

Generally, journalism and media research concerning news media presentation, analysis and influence, situate the journalist at the centre of discussions. Shoemaker and Reese (1996) illustrate the centrality of the journalist in an inner circle, surrounded by different layers of supports and influences such as media and organizational routines (e.g. newsroom norms, values), and ideological considerations (e.g., race or class). Rosas-Moreno and Harp (2013) suggest that the journalists' 'truth' in the story is determined by these layers of influence, and that "journalists do not tell the truth but versions of stories they understand to be true based on what they have seen and know" (p.150). Other authors had similar views and suggest that journalists do not just report on the facts as news but elaborate on key aspects of the story, so as to capture and influence the perceptions of their audience on the issues which they themselves struggle with or are empathetic towards (Siverstone, 2007). Essentially, some researchers describe the journalist as being in control of the story, but not necessarily with the intent of giving voice to the people in the story. Schneider (2011) suggests that the media journalists reporting on homelessness select their stories and quotes in a manner which contributes to marginalizing and excluding the people who are homeless, and this needs to be changed "to promote the social inclusion and citizenship of marginalized others" since

participation in society depends on being able to find a voice in the media. The ways in which and the degree to which homeless people are quoted in newspaper reporting of homelessness thus have implications for those who experience homelessness. Quotes from homeless people themselves promote a narrative of homelessness that marginalizes the people who experience it and contributes to their social exclusion (2011; p.1).

Still others state that journalists need audiences to communicate to or with, but they do not necessarily have an obligation to please their audience or give the audience what it desires to read or hear. Some journalists would say that their story is not impacted by society or the public interest (Protess et al., 1991) or political agendas, but others would say that as members of the Society of Professional Journalists they are a "socially responsible press" (p.73) and believe in "the public's right to know" what is happening when and where. Their stories should enlighten the public, expose societal and individual wrong-doing, activate the conscience of citizens and promote the public interest (Protess et al., 1991). If the story is socio-politically compelling, activists or advocates will 
rally the politicians and decision makers and attempt to frame the homelessness discourse to influence the social and political agendas and decisions (Edelman, 1988).

Some researchers claim that the newspaper journalists construct their own reality of issues through the explicit framing of their public relations messages and images (Hallahan, 1999), and thus, directly and purposefully influence societal or public opinion about topics such as homelessness (Buck, Toro, \& Ramos, 2004). Others suggest that the public looks to the journalists to be influenced and impacted (Soukup, 2002). However, to what extent a journalist has any such influence on the public is not clear (Lee, Link \& Toro, 1991), just as it is not clear to what extent the public draws its images and forms opinions based on what and how the journalist portrays the person or family who is homeless and their circumstances. Specifically in reference to journalists framing their stories, the literature has much to offer. Entman (2007) suggests that

to frame is to select some aspects of a perceived reality and make them more salient in a communicating text, in such a way as to promote a particular problem definition, causal interpretation, moral evaluation, and/or treatment recommendation for the item described. (p.52)

The frame can be manifested in various framing strategies such as choice of words, language and style of writing with metaphors, exemplars, descriptions, arguments and visual images (Scheufele \& Tewksbury, 2007; Van Gorp, 2007). Hallahan (1999) described seven models of framing, each with different implications for public relations. Calder et al. (2011) specifically described how these models of framing in addition to the influences of journalistic norms, organizational routines and individual journalist profiles, impact the stories regarding people who are homeless and their situations. The different types of framing and influences can create different impacts. As an example, conflict framing can be associated with stories about communities displaying not-in-my-backyard attitudes (NIMBYism) in opposition to community development of low cost housing in their neighborhood. The story is given certain attributes and levels of importance by the journalist, and it results in agenda-setting or agenda-building (Weaver, 2007) with social and sometimes political ramifications, either negative or positive. It can be assumed that such a packaged message would very likely stir the public's emotions, positively or negatively, depending upon the situation. On the one hand, a large volume of favorable attention to this matter in the media, and of reaction by the public, could result in decisions to develop and approve policies to address the situation (Buck, Toro \& Ramos, 2004). On the other hand, if the media's and consequently public's responses are negative and harsh, it is more likely that policies will not be developed to support programs, services or initiatives for homeless people. Not only is the public influenced by the media, but so are the attitudes and opinions of politicians and government level policy decision makers (Hutson \& Liddiard, 1994; Lee, Link \& Toro, 1991).

Content analysis of media articles adds to the discussion about journalists' portrayal of people who are homeless or their situation generally (Buck, Toro \& Ramos, 2004; Richter et al., 2010; Richter et al., 2011; Schneider, 2011; Mao et al., 2012). There are many topic areas in homelessness and many angles which journalists can take on any one story, but as with any person in a position of influence, media journalists are also bound under ethical conduct codes to be truthful and accurate in the stories they write or broadcast. The social responsibility theory comes closest to reflecting what a journalist should fulfill as commitment to being a member of a "socially responsible press" (Bunton, 1998, p.233). This links with the social constructionist views as well (Forte, 2002; Shields, 2001) which claim that the media define the reality of the targeted individuals in their stories as often being either at one extreme or the other - that is, good or bad. Individuals are described as either virtuous heroes or indigent losers. Often, the media will construct political, economic or social problems that identify specifically with people who are homeless and their situation. Who is targeted in the story in terms of the 'hero' or the 'indigent' will depend upon the thrust of the situation and the interests of the public in knowing about a specific controversy regarding the homeless. The journalist can either depict this in a way which invokes sympathy for the homeless by the public, or something quite the opposite (Forte, 2002).

Several authors argue that the 'blaming' of the homeless as described in some critical media articles are not accurate in their portrayal of the homeless or of their situation (Olstead, 2002; Whang \& Min, 1996). Their studies suggest that the media often put the homeless under the microscope and portray them as drunk, stoned, crazy, sick and abusive of drugs and people, which some would argue are not accurate descriptors without the consideration of other societal factors or social determinants. These are areas which present with many questions about the truths, biases or other values that journalists impart in their portrayal of people who are homeless and of their real life situations and challenges.

\subsection{Purpose and Objectives of Study}

By analyzing the motivation of different media professionals we will better understand their social responsibility and where they feel their professional responsibilities lie. This specific area has not been explored in conjunction 
with other areas of journalism or media analysis, and we found this was a noticeable gap in the literature.

Considering the context of political, economic and social aspects in Alberta over the past five years, the purpose of the study was to (1) gain an understanding for how and why media professionals described the homeless and homelessness issues; (2) explore the framing or agenda building of media stories by media professionals; (3) explore and discuss the social responsibility of the media in influencing the public's opinions, attitudes, and images of homeless and homelessness situations/issues; and (4) describe the media's interpretation of the public's and policy maker's understanding and reaction to the stories.

\section{Method}

A mixed methods (Morse \& Niehaus, 2009) single case study design (Yin, 1994) was used, in which Alberta journalists were surveyed and interviewed.

\subsection{Exploring Journalists' Perceptions of the Homeless: Study Survey and Interview Design}

A search of the media and journalists' literature revealed one survey conducted in 1989 (Protess et al., 1991) focusing on investigative reporting and editors, and their access to public information, issue identification, and market analysis. Further discussion took place with the Executive Director of the Alberta Chapter of the Canadian Association of Journalists regarding survey and interview development to explore with journalists their experiences in writing or reporting about homelessness and people who are homeless. There were no locatable surveys to guide this topic inquiry. The authors, therefore, sought the advice of journalists through the Alberta Chapter, to assist with the design approach for survey and interview questions, in order to achieve the purpose and objectives of the study. A web-based survey was selected as the choice for reaching journalists. It was developed utilizing Survey Monkey which provided anonymity and was viewed as the easiest and fastest for participants to respond to between writing and reporting. Questions included some generic demographic questions adapted from the Protess survey. Twenty-four additional questions were designed utilizing very quick response approaches including 'yes/no', checklists and some ranking/rating on a scale from one to ten. Some of these had open-ended questions for clarity or additional information. Questions explored the journalists' professional and personal perceptions and accounts of homeless people and homelessness issues, the topics they wrote about, their targeted audience, what motivated them to write on this topic in the news media, their portrayal or framing of the homeless and homelessness issues to their audience(s), and if they had received comments from their readers or select interest groups. The developed online survey was piloted with the Executive Director and three other journalists to ensure survey reliability and content validity. The piloted survey was approved by the Chapter for dissemination to its members.

Using a semi-structured interview guide, interviews followed similar questioning from the surveys to confirm the results of the surveys, but with the intent of clarifying and enhancing their survey responses.

\subsection{Participant Characteristics}

Participants to complete the survey were recruited through email invitations via the Canadian Association of Journalists and public directories of media companies, which consented and provided access to approximately 400 media professionals in Alberta. Participants who logged onto the survey site and completed the survey voluntarily consented as the survey was an opt-in request. Those who completed the survey were also asked to consent to provide their contact information at the end of the survey, if they were willing to participate in a follow-up interview. Further written informed consent was obtained from participants prior to the interview and being audio-taped. Ethical approval for the study was obtained (Health Research Ethics Board, Panel B, University of Alberta).

\subsection{Data Analysis}

The survey data were analyzed using descriptive statistics (percentages and frequencies), while the interview transcripts were analyzed using an interpretative thematic approach, with two independent investigators coding the transcripts to ensure inter-rater reliability and validity of the resulting themes. Any discrepancies were discussed and decisions made jointly. The interview data were analyzed concurrently with the survey data collection so as to ensure that there was consistency and completeness of the interviews with the survey results, as per mixed method approach.

As a note, it was intentional that an analysis of newspaper articles in Edmonton and Calgary was not done for this study so as to maintain the confidentiality of the participating journalists. Media story analysis on homelessness and related topics in Alberta was part of another study and published elsewhere (Richter, Kovacs Burns, Chaw-Kant, 2010) 


\section{Results: What Journalists Perceived about Their Stories on the Homeless and Homelessness}

\subsection{Survey Results}

Fifty-five of potentially 400 media professionals completed the survey (14\% response rate). Table 1 shows the characteristics of the survey respondents $-71 \%$ were newspaper journalists, and about half had 5 to 25 years of experience.

Table 1. Characteristics of survey respondents $(n=55)$.

\begin{tabular}{cl}
\hline Profession & Percent (\%) \\
\hline Newspaper journalists & 71 \\
Television reporters & 13 \\
Radio broadcasters & 9 \\
Other & 7 \\
\hline Years of experience & \\
\hline$>25$ years & 29 \\
5-25 years & 51 \\
$<5$ years & 20 \\
\hline
\end{tabular}

Over $56 \%$ of the participants said they had written a story on homelessness in one main urban centre. More specifically, 64\% had written about the people who are homeless, while $78 \%$ wrote about the factors and circumstances related to homelessness. A large variety of topics were investigated and reported as indicated in Figure 1.

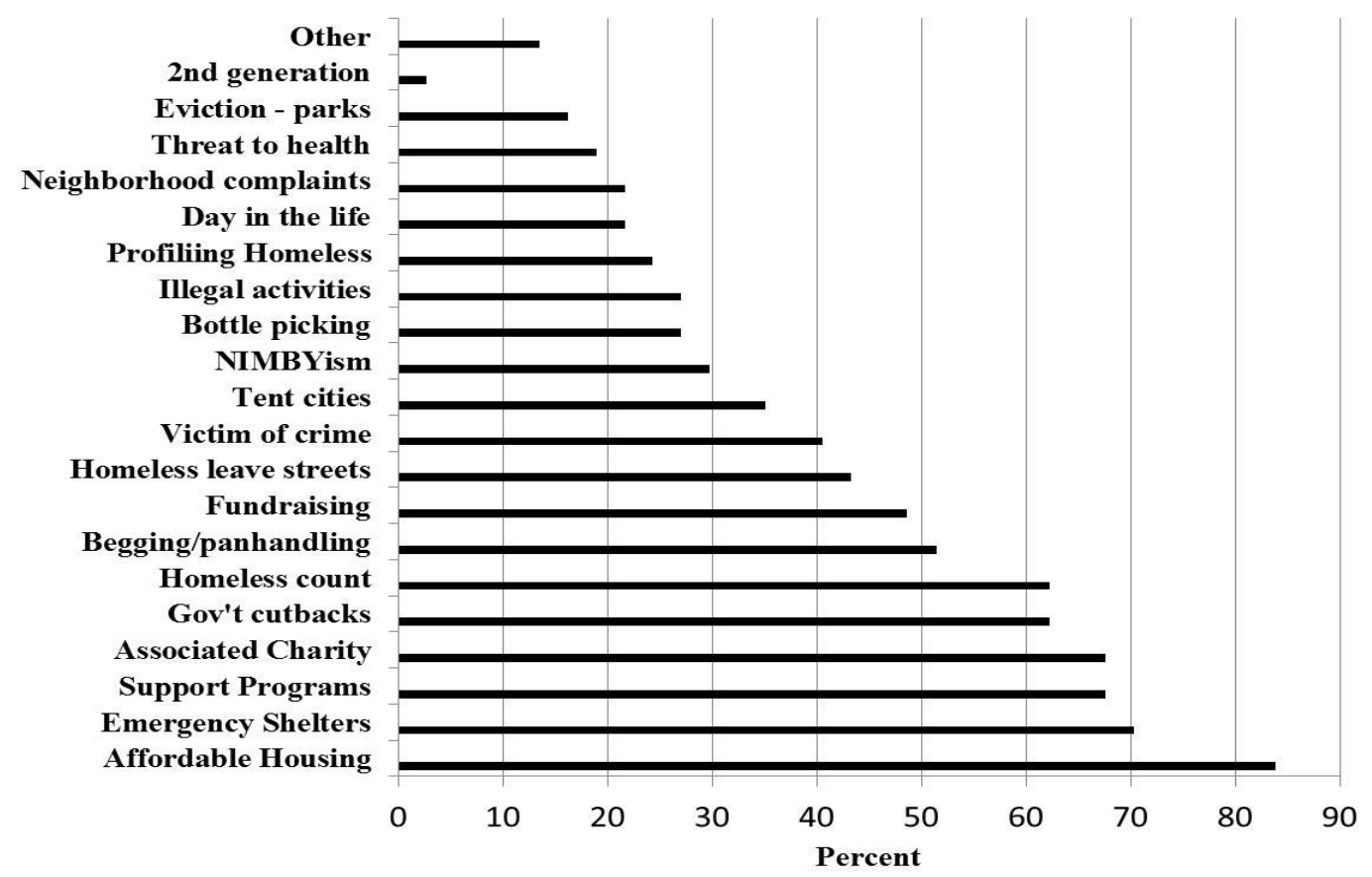

Figure 1. Percent of story topics written by responding journalists $(\mathrm{n}=55)$

'Affordable housing' issues topped the list for the number of stories written (83\%) with five other topics written about by more than $60 \%$ of respondents (emergency shelters, support programs, charity, government cutbacks and homeless count). The least reported topic was 'second generation homelessness' $(<5 \%)$.

The majority $(60 \%)$ of journalists had written less than five stories but $8 \%$ had written more than 20 stories. Through their stories they directly targeted the public as readers (97\%). However, more than one-third also targeted decision or policy makers, and more specifically government officials $(24 \%)$, politicians (27\%), and social service providers (24\%). $19 \%$ felt they were advocates and could make a difference through their stories. The majority were never sure if their stories ever made a difference in helping a cause or situation (73\%). More than three-quarters of respondents thought that the homeless situation was not exaggerated by the media, service providers, public, politicians, homeless population or researchers.

Opinions were mixed on how their perceptions or attitudes influenced their stories. One-half of the journalists thought that their personal attitudes or perceptions influenced their portrayal of the homeless in the media, while 
another third disagreed. In fact, more journalists disagreed than agreed that they targeted and influenced specific audiences with their stories. This was contrary to the earlier question and response on this topic. By the end of the survey, journalists commented that more attention could be given to the people who were homeless and homelessness issues in the news, and therefore more stories were needed (72\%). They also said that media could do a better job at profiling the homeless (87\%) and enhancing the public's understanding (72\%).

\subsection{Interview Results}

Of the 55 surveyed media professionals, 10 consented to being interviewed. Interviewees consisted of three columnists, four reporters and three editors. Their current and past work history varied, and included the one Web-Editor who had been in this role for only six months at the time of the interview but who had been a journalist for 30 years in total. Another respondent had been a reporter, columnist and editor for over 36 years. While the most recent media professional had eight months experience as a journalist, there were five with 3-5 years and two others with 15 years of experience.

All 10 journalists had written about the homeless prior to the study, that included a mix of news articles, editorials, letters or opinion pieces, community news columns/events, and other news pieces. Five commented that their years of work-related experiences contributed to their beliefs that what they wrote was neutral, and four felt they were more positive than negative in what they wrote about homelessness.

The themes arising from the analysis of the surveys and interviews are shown in Table 2. For some of the themes, there were sub-themes and issues that illustrated the diverse and explicit perceptions of the media professionals on the topic of homelessness and on people affected.

Table 2. Summary of Themes, Subthemes and Issues from Analysis of Journalists' Interview Transcripts

\begin{tabular}{|c|c|c|}
\hline Main Theme & Subtheme & Issues to be Discussed \\
\hline Views on Objectivity (bias) & Differences in media & Different roles in media reporting \\
\hline Media's Accountability & $\begin{array}{l}\text { Social Responsibility } \\
\text { Social Justice }\end{array}$ & \\
\hline Motivation for writing a story & $\begin{array}{l}\text { Critical Incidence } \\
\text { Business/Credibility } \\
\text { Humanize Homeless Population } \\
\text { Create a reaction }\end{array}$ & $\begin{array}{l}\text { Sensationalize } \\
\text { Specific issues } \\
\text { "White-middle-class"Society } \\
\text { NIMBYism } \\
\text { Change public's views } \\
\text { Endorse private charity }\end{array}$ \\
\hline \multirow[t]{3}{*}{ Homelessness } & Reasons for Homelessness & $\begin{array}{l}\text { Choices } \\
\text { Mental Illness } \\
\text { Addictions } \\
\text { Housing issues } \\
\text { Working homeless }\end{array}$ \\
\hline & System Barriers & $\begin{array}{l}\text { Shelters } \\
\text { Political } \\
\text { Health care } \\
\text { Social/Academia } \\
\text { Strain/social control theory } \\
\text { Problems getting out of poverty }\end{array}$ \\
\hline & $\begin{array}{l}\text { Views on Interventions } \\
\text { Personal experiences } \\
\text { Influence on views }\end{array}$ & Recommendations/solutions \\
\hline \multicolumn{3}{|l|}{$\begin{array}{l}\text { Participants desired } \\
\text { portrayal of homelessness }\end{array}$} \\
\hline $\begin{array}{l}\text { Media's beliefs of the } \\
\text { homeless population }\end{array}$ & $\begin{array}{l}\text { Stereotyping } \\
\text { Stigmatization } \\
\text { Myth } \\
\text { Visibility }\end{array}$ & Aboriginal \\
\hline Feedback on Articles & $\begin{array}{l}\text { Service providers } \\
\text { Public } \\
\text { Politicians }\end{array}$ & \\
\hline
\end{tabular}




\subsubsection{Views on Objectivity and Accountability}

Interviewees claimed that different media professionals have different levels of freedom to publicly express their personal opinions, interests, and biases. For example, an editor described his short career as beneficial because he believed he was in a position where he could choose what to write about:

I know that my biases will most definitely impact what I write about the homeless and I think it is morally imperative for anyone, a journalist to inform the public to the best of their ability and that includes your own biases.

Others confirmed this view, and suggested that objectivity was not necessarily achievable because "personal perceptions are always going to influence the choices that people make when they are looking for contacts or who they decide to call and who they decide not to call". However, one of the most important points made by the media professionals regarding these views is their accountability to their profession and to the public to tell the truth and present the facts.

\subsubsection{Motivation to Write About the People Who Are Homeless}

When asked what motivated them to write about the people who are homeless or homelessness issues, about $70 \%$ of the survey participants said they wrote the stories because that was their job. This response overlapped with other answers in the survey as well, one of which was that a public issue arose and the story was therefore timely and strong (62\%). Correspondingly, some of these participants also claimed they were personally interested in specific aspects of the topic (65\%). In this latter case, their stories mainly focused on topics shown in Figure 1, including affordable housing, emergency shelters, support for the homeless and charities associated with homelessness.

The interviews confirmed that the majority of the topics the media professionals chose to write about were the same ones being discussed by different neighborhoods, levels of government or non-profit organizations trying to cope with the homelessness situation. The journalists utilized these sources for gathering information and facts for their stories, but the majority of their information came directly from those affected or who took a personal interest in the homeless and their situation. Individuals identified included service providers/frontline workers, homeless people, politicians, researchers and police officials.

During the interviews, the media professionals said they were motivated to write their stories about homelessness usually because of the occurrence of some type of critical incident involving the homeless. One journalist stated that he/she would write if there was a development of a critical situation such as "a lack of shelter space or there had been an assault on somebody who was homeless, when there were changes to homeless strategies... or if it is newsworthy."

The stories were primarily written with the intent of either enhancing awareness or changing public views about the issues faced by the homeless, right in the 'backyards' of the public and decision makers. The participants were asked if they had written a story on homelessness that made a difference in a homeless person's life, to which one journalist said: "Yes, I once wrote a feature on homelessness and housing for the mentally ill which I was told influenced some decision makers when it came to a funding issue".

Several participants discussed how important it was to frame a story and capture the public's interest. This often involved sensationalizing and creating a hook for a story to attract the public. Other participants described the difficulties with writing on homelessness, including its complexity and the fact that homelessness was an issue that had been discussed for decades with often nothing new to report.

All of the participants perceived homelessness as an issue that frequently needed to be brought to the forefront, and six of them mentioned "humanizing the homeless population". Participants further elaborated that a story should be created about the life of a homeless person and should connect the people to the issue, particularly since they felt their audiences often seemed to be disconnected from what it was really like to be homeless. One participant mentioned that the public used repression as a "social coping mechanism" for dealing with homelessness, and therefore, one of the media's tasks was to break down any barriers to changing public perceptions.

Barriers to writing about homelessness included the public's interests, and the media's drive to market their products to make a profit and continue their business. One journalist described newsworthiness as "something the editor considers most relevant. These are issues important to the public... something that shocks people or surprises them or pisses them off." Two journalists also discussed the importance of retaining credibility when writing articles because to them "credibility is currency" and it was important not to diminish credibility and sacrifice the article to promote someone's agenda. They described the downfalls of advocating for any one cause 
in a news-oriented business because it could be viewed negatively by the audience, regardless of the cause, and often resulted in a loss of profit.

Social responsibility was a theme that presented itself in the majority of the interviews. The term was mentioned as a belief the journalists shared when they expressed their desire to raise public awareness about homelessness. This belief was described as "a sense of responsibility to function as a kind of social conscience of the community... and keep it on people's radar." The desire to provide a form of medium in which the homeless community can influence the public was paramount throughout the interviews and this coincided with the image they wanted to project to the public.

\subsubsection{Personal Views on Homelessness}

Media professionals indicated that aside from sustaining the media as a business, they also had their own personal views on homelessness. Five of the journalists said they were sympathetic to the plight of the homeless ("Very complex issues with people who have both been failed and have failed themselves"). Three were empathetic, particularly for those with illnesses as well as being homeless ("I have empathy for the mentally ill"); two felt they were neutral ("I try never to get emotionally involved in my stories, no matter what the subject"); and one said he/she had negative feelings towards the homeless. "I understand that there are many reasons for being homeless (addictions, mental health) but at the same time I feel negatively towards people who live this lifestyle."

\subsubsection{Views on Reasons for Homelessness}

Many of the media professionals shared similar views on the causes of homelessness regardless of their current media position or past experiences. Examining their perceptions for why people were homeless was important because this determined what media professionals focused on in their stories.

Nine of the ten journalists discussed their views openly about choices and homelessness. There was a mix of beliefs as to whether or not some homeless people actually chose to be homeless. On journalist stated it was "something of their own making, they choose to be there. I'm a pretty conservative person and I think you have to take responsibility for your own self". Other participants clearly stated the opposite - that people were not homeless by choice but rather because of "bad luck" and suggested that multiple reasons can be attributed to their situation. A new journalist displayed an empathetic view and described the situation as a result of circumstances beyond their control:

it just takes one moment of your time to change everything, to either get a diagnosis of mental illness or leaving an abusive relationship and nowhere to turn, getting evicted from your apartment for some reason and not having a financial net that you know you can turn to.

Some specific reasons for homelessness identified by journalists included mental illness, addictions, housing, and other general issues. Nine of the 10 interviewees made reference to mental illness directly related to homelessness. They elaborated on the inability of our current health care system to correctly treat the illnesses of the homeless. For example, deinstitutionalization of people who were mentally ill was seen as a major cause for increased numbers of them living on the street or in a shelter. The participants discussed a wide range of variables for mental illness and how the different aspects of dealing with it could make things even more difficult when they are homeless. These included being stigmatized, and challenges being compliant with buying and/or taking their prescribed medications.

Addiction was also recognized as a facet of mental illness, but this was not viewed as the norm. Substance abuse was mentioned as a poor lifestyle choice that resulted in the loss of a home and social supports. Because of the damaging nature of certain addictive substances, the effects of addiction was often inappropriately associated with homelessness, especially as recovery was difficult in the best circumstances but much more difficult to attain when one was homeless.

Several systemic reasons were also linked with homelessness. One was associated with the term "working homeless" which was directly related to the lack of affordable housing. This term was generated as recognition of people who worked minimum wage jobs and were not able to sustain adequate housing for themselves and their families.

\subsubsection{Views on System Barriers and Interventions}

Journalists expressed concerns about system barriers. They all felt there was a need for improvement in certain areas of public resources and access to these resources. They emphasized four main systems that needed more attention - shelters, the political system, health care barriers and inadequacies of academia in making a 
difference. Journalists described their surprise when interviewing homeless people and finding that conditions in shelters were unsuitable for their use. They also mentioned unrealistic policies (alcohol prohibition) which deterred some homeless from using shelters.

Three participants commented directly on the inefficiency of current and past governments to improve the homelessness situation in Edmonton. They described the lack of insight on behalf of the government when implementing policies, and determined that the effects of many policies were ineffective in addressing the issues of the homeless. One journalist acknowledged the "general lack of willingness from higher level government [to deal with homelessness] because it's a complicated and difficult problem to solve." The political system was of concern for many of them because they recognized the influence of political institutions on other institutions and groups that required resources to provide the much needed programs and services for the homeless.

Health care was regarded as one of the primary system barriers for the homeless population because some people perceived that there was a direct correlation between a person's health (physical and mental) and their resulting homelessness situation. The journalists expressed concern about the effects of cutbacks in health care and how it allowed people to "fall between the cracks." An example of this is the point of access for homeless people to the health care system. One journalist expressed her concern about the conditions of the emergency room (ER):

the number of people coming to ER [Emergency Room] are not there needing acute medical attention, they are mentally ill, they're addicted, their schizophrenic, they're bipolar, ...beds that are needed for people having heart attacks or car accidents are being taken up by people who have nowhere else to go, and I don't blame those people for using the ER because that's their only point of access to get any kind of health or social services.

There was a general feeling of concern over the direction of the health care system and a need to improve the management of facilities intended to assist vulnerable populations.

Academia was also not viewed favorably by the media with regards to social research. Three journalists claimed social research had very little impact on the community, and was not attractive to their particular readership. Recommendations made by the participants to improve the effects of social research included practical solutions and attempts at various intervention methods to assist the homeless.

\subsubsection{Personal Experiences Influencing Views}

Five of the participants reflected about their personal experiences with homelessness -- either someone they loved or their own personal experience. A particular journalist shared that his experience on the street was negative but it allowed him to gain an appreciation for the reality of homelessness. He stated the importance of education along with knowing how to access critical resources, as essential for developing an avenue to escape. Others cited experiences which included friends and family who struggled with homelessness, or in which they witnessed homelessness in a way that changed their perceptions of it.

Growing up with a substantial amount of homeless people in a large American city had significantly influenced the perception of one of the newer journalists. He was continually told by his parents to avoid these "bums" and he perceived them as shadows in the dark that may harm him. Through his own life experiences and societal awareness he developed a new outlook on homelessness and viewed it as a result of more external factors such as a failure of the health care system and social safety nets. All of these personal experiences by the various media professionals were said to have had positive impacts on their ability to write about homelessness, providing insight and character to their articles.

\subsection{Media's Beliefs and Desired Portrayal of Homelessness}

Examining the media professional's perception of homelessness provided a more thorough understanding of his/her involvement in creating, or maintaining a certain image of homelessness. As a result of the thematic analysis of the ten interviews, we identified four major areas describing the image of homelessness, either from a personal perspective or from how their readers viewed homelessness. The two sub-themes that best described the images identified by media professionals were stereotype/stigmatization and visibility of the homeless.

\subsubsection{Stereotype/Stigmatization}

Stereotyping or stigmatization of the homeless by the general population was arguably one of the largest contributing factors to the poor quality of life for homeless persons. One journalist described the uncomfortable feelings of a person walking down town and being approached by a homeless person. The journalist further stated that "people are scared of them [homeless persons] and don't feel sorry for them one bit. They want them to go away." Characteristics used to describe the homeless from the interviews included "aggressive", "drunks", 
"lazy", "mentally ill”, "addicts", "dirty", "smelly", and many others.

The feelings resulting in stereotyping or stigmatization were often the same ones associated with a sense of mysticism surrounding homelessness. The journalist who spent 35 years in media, felt this mysticism. He was able to provide his insight about homelessness years ago and compare it to the current circumstances. He discussed the original images of homeless persons as those from prisons and work houses and how they were considered a public nuisance. He stated that the public's fear and attitude towards the homeless had not improved over the years. The same problems related to stigmatization.

\subsubsection{Visibility of the People Who Are Homeless}

Aboriginal people were often stigmatized in stories. One journalist commented on her views about overrepresentation of aboriginal people in homelessness, and their challenges when moving or migrating to the city from the reserves. She described it as "corruption on the reserves and breakdown of social safety nets on the reserve and the factors that push people to come into the cities and then lack support... when they do come into the cities". This led into her discussion of how the influx of aboriginal people strained the city's ability to provide social programs and financial support to families dealing with poverty.

The location and visibility of homeless people was the cause for most people's interest in homelessness because it was relevant to their daily lives. For some of the journalists the visibility of homelessness was associated with the city centre area in close proximity to the shelters. One of the major challenges of the media was presenting the scope of homelessness in major cities because there tended to be a focus on the inner-city population, when in fact the homeless were generally located in different sectors of a city. The discussion of NIMBYism (Not In My Backyard) was mentioned in this context of planning Housing First accommodation for the homeless outside of the inner city area. Although the public wanted more shelters provided for the homeless, they complained when shelters were planned for construction in their communities.

\subsubsection{Images the Media Wanted to Portray}

When asked what image they wished to portray, an overwhelming response was making the public aware of how significant and complicated the issue of homelessness was. The journalists felt that the public was ill-informed on the issue of homelessness and was not aware of how enormous the problem was, or how it reflected the lack of city resources. Examples of journalists' comments included: "There is one thing that I like for people to know - that it is a bigger problem than most people realize."

There is no single image...it is a complicated thing in the sense that homelessness is a product of a lot of different things"; and "I would like to show that the public's perception of homelessness is not...a lot of the times reality. There are a lot of people out there who are homeless (and) it's not their own fault."

\subsubsection{Public's Feedback on Articles}

Many of the journalists had a range of experiences with feedback from different sources, such as service providers, the public, politicians, and private charity groups. The majority of participants stated they had positive feedback from these sources and felt that their writing was having a positive impact in the community. Five journalists talked about how certain articles inspired private companies to sponsor hot lunches for children or for people to donate money to various organizations such as Habitat for Humanity, the food bank and community support centres. The majority of feedback received by the journalists was from service providers who felt that the media had given them support for their cause and that they appreciated the articles being written.

However, there were people who had given negative feedback because they felt the issue was not properly presented or had racial overtones. One participant discussed her difficulties with an aboriginal community who felt it was not appropriate for the journalist to write on aboriginal homelessness because she was not aboriginal herself.

Homelessness issues also had political impacts when certain political groups tried to change a policy, or address it on their campaign platform. Because the media could influence public opinions, political persons might have felt threatened by the media trying to influence the issue by what and how articles had been written. One journalist commented: "I've had politicians call and criticize and yell and scream at us and threaten to take us to court and that kind of thing, but that's different from trying to influence how you cover a particular story".

\section{Discussion}

To determine how and why the media journalists communicated their 'frames' of people who were homeless, it was important to understand the people who were the media professionals. Our findings suggested there were four major influences impacting media professionals in their portrayal or framing of the homeless and their 
situations. These four influences were (1) the current and past experiences of the participant; (2) the participant's distinction between professional and personal perceptions, beliefs and experiences; (3) the participant's social responsibility to the public, and (4) the responses of the public or decision makers to issues or news stories. Social construction and framing theories apply such influences in the explanation of how and why media professionals portray the homeless and their situations, as they do.

Local media centers symbolized the interconnectedness of the media professional with a community (Bunton, 1998). Communication, as in informing the public, was a key role for the media which placed significant social responsibility on journalists to provide true and accurate accounts. However, the essence of media social responsibility was defined as an: "affirmative role in advocating social justice for citizens who are powerless. The litmus test of whether or not the news profession fulfills its mission over the long term is its advocacy for those outside the socioeconomic establishment" (Bunton, 1998). The human-ness of the media professionals was what needed to be considered in how and why they portrayed the homeless as they did. Some media professionals were greater advocates than others. Generally, the media who were columnists had more freedom to express their opinions than reporters.

On the one hand, making the homeless visible was recognized by the journalists as a fundamental power they possessed, which could encourage community support. On the other hand, making the homeless people more visible also had negative consequences depending on the image portrayed to the readers. Homeless people had no power against the media or public. The result was that the homeless became vulnerable in all ways to other more influential groups (Forte, 2002).

Politicians and community activist groups were viewed as prioritizing needs of vulnerable populations, while the effective claims of the media were to publicize homelessness and make it marketable (Forte, 2002). The benefits in this latter case were mutual between the media and the community. The results could be seen in some community efforts, programs and services being supported by different levels of government, which otherwise might never have been acknowledged by these governments. One could conclude that when the media cast the vote for the public, the politicians take note.

The media have influenced the publics' perceptions, such that the more stories there were that emphasized the same points, the more likely the public would respond. In the past, the media focused on individual stories conveying the message that homelessness was personal rather than emphasizing that system barriers were often responsible for causing people to become homeless (Shields, 2001). The media's switch in approach presented the issue or framed the people who were homeless within the issue. Then, they waited for the public's response.

\section{Conclusion}

Our results and findings from others, suggest that it is important for the public and policy/decision makers to understand the journalists behind the stories about people who are homeless and their situations. Although, not totally without subjective feelings or empathy, the media professionals are in a unique position to accurately report and investigate the homeless situation in the community in a way which can make a social difference. Perhaps, the path of influence on social issues topics such as homelessness, is not as linear as thought - that is, it is not necessarily true that the journalist solely influences the public or policy maker, but that the journalist is also influenced by the response or lack of response and the impact this has on those who can make a difference in the outcomes of individuals or families who are homeless or vulnerable to becoming homeless. Many of the journalists who have been in the media business for quite some time not only have a perspective about the homeless and their situation, but can also make some credible recommendations for changes to improve the situation for the homeless and for the community as a whole. Through the interviews with the journalists, it is clear that they have a strong understanding of the social, health and other systems we all deal with. Their investigations into the background for their stories as well as the information they gather through their interviews or contacts, provide them with the evidence which informs their story and frames the portrayal of the person/people in the story and their situations. The journalists state that they have social responsibilities to support social justice - this in itself is their motivation for writing the stories they do. Through the framing of their stories on the homeless and homelessness issues, the media professionals can be considered exemplars of social construction in action.

\section{Acknowledgements}

The authors express their gratitude to the Western Canadian Broadcasters Association for their assistance with disseminating information about the study to their 400 Alberta media members. The study was funded by a University of Alberta Killam Grant. 


\section{References}

Alberta Secretariat for Action on Homelessness. (2008). A Plan for Alberta: Ending Homelessness in 10 Years. Edmonton: Alberta Government, Retrieved from http://alberta.ca/albertacode/images/AlbertaPlantoEndHomelessness.pdf

Alberta Secretariat for Action on Homelessness. (2013). A Plan for Alberta: Ending Homelessness in 10 Years. Three Year Progress Report. Edmonton: Alberta Government. Retrieved from http://humanservices.alberta.ca/documents/homelessness-3-year-progress-report.pdf

Buck, P. O., Toro, P. A., \& Ramos, M. A. (2004). Media and professional interest in homelessness over 30 years (1974-2003). Analyses of Social Issues and Public Policy, 4(1), 151-171. http://dx.doi.org/10.1111/j.1530-2415.2004.00039.x

Bunton, K. (1998). Social responsibility in covering community: A narrative case analysis. Annals of Mass Media Ethics, 13(4), 232-246. http://dx.doi.org/10.1207/s15327728jmme1304_3

Calder, M., Richter, S., Kovacs Burns, K. et al. (2011). Framing Homelessness for the Canadian Public: The News Media and Homelessness. Canadian Journal of Urban Research, 20(2), 1-19.

Canadian Homelessness Research Network. (2012). Canadian Definition of Homelessness. Homeless Hub: www.homelessnesshub.ca/CHRNhomelessdefinition/

Cress, D. M., \& Snow, D. (2000). The outcomes of homeless mobilization: The influence of organization, disruption, political mediation, and framing. American Journal of Sociology, 105(4), 1063-1084. http://dx.doi.org/10.1086/210399

Edelman, M. (1988). Constructing the political spectacle. Chicago: University of Chicago Press.

Entman, R. M. (2007). Framing bias: Media in the distribution of power. Journal of Communication, 57, 163-173. http://dx.doi.org/10.1111/j.1460-2466.2006.00336.x

Faid, P. (2009). Poverty Reduction Policies and Programs, Extending the Alberta Advantage. Canadian Council on Social Development. Social Development Report Series 2009. Retrieved at http://www.ccsd.ca/SDR2009/Reports/AB_Report_FINAL.pdf

Forte, J. A. (2002). Not in my social world: A cultural analysis of media representations, contested spaces, and sympathy for the homeless. Journal of Sociology and Social Welfare, XXIX(4), 131-157.

Gaetz, S., Donaldson, J.. Richter, T. \& Gulliver, T. (2013). The State of Homelessness in Canada. Toronto: Canadian Homelessness Research Network Press. Retrieved at: www.homelesshub.ca.

Hallahan, K. (1999). Seven models of framing: Implications for public relations. Journal of Public Relations Research, 11(3), 205-242. http://dx.doi.org/10.1207/s1532754xjprr1103_02

Hulchanski, D., Campsie, P., Chau, S., Hwang, S. W., \& Paradis, E. (2009). Homelessness: What's in a word? In Finding home: Policy options for addressing homelessness in Canada, D. Toronto, ON: University of Toronto. Retrieved at: http://www.homelesshub.ca/FindingHome.

Hutson, S., \& Liddiard, M. (1994). Youth homelessness: The construction of a social issues. London: Macmillan.

Iyengar, S., \& Kinder, D. R. (2010). News that matters: Television and American opinion. Chicago: University of Chicago Press.

Kendall, D. (2005). Framing class: Media representations of wealth and poverty in America. Lanham, MD: Rowman \& Littlefield.

Lee, B. A., Link, B. G., \& Toro, P. A. (1991) Images of the homeless: Public views and media messages. Housing Policy Debate, 2, 649-682. http://dx.doi.org/10.1080/10511482.1991.9521068

Mao, Y, Richter, S, Kovacs Burns, K., \& Chaw-Kant, J. (2012). Homelessness Coverage, Social Reality, and Media Ownership: Comparing a National Newspaper with Two Regional Newspapers in Canada. Journal of Mass Communication Journalism, 2(7), open access. Available at: http://dx.doi.org/10.4172/2165-7912.1000119.

Morse, J., \& Niehaus, L. (2009). Mixed method design: Principles and procedures. Walnut Creek, CA: Left Coast Press.

Newspaper Audience DataBank Inc. (2007-2012). Newspaper Circulation Readership Trends: Why Newspapers? Is it really a news "paper"? Retrieved at www.nadbank.com. 
Olstead, R. (2002). Contesting the text: Canadian media depictions of the conflation of mental illness and criminality. Sociology of Health \& Illness, 24(5), 621-643. http://dx.doi.org/10.1111/1467-9566.00311

Protess, D. L., Cook, F. L., Doppler, J. C., Ettema, J. S., Gordon, M. T., Leff, D. R., \& Miler, P. (1991). Journalism of Outrage. Investigative Reporting and Agenda Building in America. New York: Guilford.

Richter, S., Kovacs Burns, K., \& Chaw-Kant, J. (2010). Analysis of newspaper journalists' portrayal of the homeless and homelessness in Alberta, Canada. International Journal of Child Health and Human Development, 3, 125-136.

Richter, S., Kovacs Burns, K., Mao, Y., et al. (2011). Canadian media's interest in homelessness: A longitudinal content analysis of homelessness coverage in six major Canadian newspapers from 1987 to 2007. Canadian Journal of Communication, 36, 619-635.

Rosas-Moreno, T., \& Harp, D. (2013). A comparative analysis of a shared (Inter)National story: How Brazilian and US presses covered Sean Goldman's Recovery, Studies in Media and Communication, 1(1), 150-163. http://dx.doi.org/10.11114/smc.v1i1.84

Scheufele, D. A., \& Tewksbury, D. (2007) Framing, agenda setting, and priming: The evolution of three media effects models, Journal of Communication, 57, 9-20. http://dx.doi.org/10.1111/j.1460-2466.2006.00326.x

Schneider, B. (2011). Sourcing homelessness: How journalists use sources to frame homelessness. Journalism online, 1-16. http://dx.doi.org/10.1177/1464884911421573

Shields, T. G. (2001). Network news construction of homelessness: 1980-1993. The Communication Review, 4(2), 193-218. http://dx.doi.org/10.1080/10714420109359468

Shoemaker, P. J., \& Reese, S. D. (1996). Mediating the message: Theories of influences on mass media content. 2nd ed. White Plains, NY: Longman.

Siverstone, R. (2007). Media Morality: On the Rise of the Mediapolis. Cambridge: Policy Press.

Soukup, P. (2002). Reading the homeless: Communication theory and public policy. The Review of Communication, 23, 318-320.

Van Gorp, B. (2007). The constructionist approach to framing: Bringing culture back in. Journal of Communication, 57, 60-78. http://dx.doi.org/10.1111/j.1460-2466.2006.00329.x

Weaver, D. H. (2007). Thoughts on agenda setting, framing and priming, Journal of Communication, 57, 142-147. http://dx.doi.org/10.1111/j.1460-2466.2006.00333.x

Whang, I., \& Min, E. J. (1996). Patterned image of the homeless: Discourse analysis of television news narrative. Retrieved from http://eric.ed.gov/?q=Patterned+image+of+the+homeless\&id=ED401571

Yin, R. (1994). Case study research: Design and methods ( $2^{\text {nd }}$ ed.). Thousand Oaks, CA: Sage.

\section{$(\mathrm{cc}) \mathrm{BY}$}

This work is licensed under a Creative Commons Attribution 3.0 License. 